\title{
RAYHERTKONSTANTIN,
}

PhD in Philosophy, associate professor of the Department of philosophy and methodology of knowledge, Odessa I. I. Mechnikov National University

\section{THE PHILOSOPHY OF ARTIFICIAL CONSCIOUSNESS IN THE FIRST SEASON OF TV SERIES 'WESTWORLD'}

The study analyzes the philosophy of artificial consciousness presented in the first season of TV series 'Westworld' and as a result of the analysis shows the collision of two opposite philosophical views on consciousness and the possibility of creation of artificial consciousness from the standpoint of two characters of TV series - Arnold Weber and Robert Ford. Arnold Weber proceeds from two philosophical assumptions: consciousness really exists (1) and human consciousness can be a prototype for modeling consciousness in an artificial intelligence bearer (2). And he has to choose: either to pick out one of the already existing conceptions of consciousness to implement the emergence of artificial consciousness within artificial intelligence or to invent his own; Arnold Weber chooses the Julian Jaynes' conception of consciousness as a basis for artificial consciousness what means that artificial consciousness must have the following features: 1) artificial consciousness has to be the result of the breakdown of the bicameral mind (apparently, modeled within artificial intelligence), the state of mind in which cognitive functions are divided into two part, a 'speaking' part and 'hearing' ('obeying') part, until the breakdown that makes the bicameral mind the unified mind; 2) artificial consciousness has to be a mind-space based on language and characterized by introspection, concentration, suppression, consilience and an analog 'I' narratizing in the mindspace. Robert Ford believes that consciousness does not exist at all and that there are only stories (narratives) which human beings and artificial beings, modeled in the image and likeness of human beings, tell each other and always the basis of all those stories (narratives) is suffering.

Key words: artificial consciousness; artificial intelligence; consciousness; science fiction; television; thought experiment.

Problem statement. Sometimes science fiction disposes of a material that can be considered as philosophical thought experimentation which deals with hypothetical situations which model possible probabilities [1, p. 98]: as American philosopher Susan Schneider points out, "thought experiments are imagination's fancies; they are windows into the fundamental nature of things. A philosophical thought experiment is a hypothetical situation in the "laboratory of the mind" that depicts something that often exceeds the bounds of current technology or even is incompatible with the laws of nature, but that is supposed to reveal something philosophically enlightening or fundamental about the topic in question. Thought experiments can demonstrate a point, entertain, illustrate a puzzle, lay bare a contradiction in thought, and move us to provide further clarification" [17, p. 1]. Serious science fiction works do the same: "Intriguingly, if you read science fiction writers like Stanislaw Lem, Isaac Asimov, Arthur C. Clark and Robert Sawyer, you are already aware that some of the best science fiction tales are in fact long versions of philosophical thought experiments" [17, p. 2]. The difference between them lies in the tasks: the task of philosophical thought experiment is cognition in general; and the task of science fiction is entertainment in general. One of the common issues under development in contemporary sciences and philosophy and science fiction is an extension of intellectual and physical abilities and capacities of human being by means of human enhancement technologies and artificial intelligence. The extension conjectures not only technology solutions but anthropological, ethical, philosophical, psychological, sociological and other solutions because of the fears of advanced technologies which can replace human being or just annihilate him / her. Some science fiction works are concerned with the issue of the extension of intellectual and physical abilities and capacities of human being by means of human enhancement technologies and artificial intelligence and the fears generated by the issue. One of the last vivid examples of such science fiction works is American TV series 'Westworld'.

On October 2, 2016, the first season of TV series 'Westworld' was presented by American premium cable-satellite television network HBO (Home Box Office). The creators of the TV series were Jonathan Nolan and his spouse Lisa Joy. The TV series actually is a remake of Michael Crichton's motion-picture film 'Westworld' (1973) and its sequels: Richard T. Heffron's motion-picture film 'Futureworld' (1976) and Michael Crichton's five-part TV series 'Beyond Westworld' (1980). The TV series had the network's highest viewership ratings [3] and mostly the positive critical reviews.

Analysis of research and publications. The very first episodes of TV series 'Westworld' drew attention of philosophers, scientists, scholars and academics who work 
in the fields of theoretical and practical development of artificial intelligence $[4 ; 10 ; 14]$ including famous American philosopher John R. Searle who gave the clear uptake that consciousness was a biological phenomenon which couldn't be recreated within a computing machine [6]. Furthermore, TV series 'Westworld' was analyzed in the context of ethics [15] and political philosophy [9; 13]. Eventually, popular book series 'The Blackwell Philosophy and Pop Culture Series', in the person of two editors, Susanne E. Foster and James B. South, announced the admission of essays to collection 'Westworld and Philosophy' [19].

The purpose of the study is to analyze the philosophy of artificial consciousness (i.e. of machine consciousness or synthetic consciousness) presented in the first season of TV series 'Westworld'.

Presentation of the main material. Briefly, the plot of the first season of TV series 'Westworld' is stated in HBO synopsis: "The one-hour drama series Westworld is a dark odyssey about the dawn of artificial consciousness and the evolution of sin. Set at the intersection of the near future and the reimagined past, it explores a world in which every human appetite, no matter how noble or depraved, can be indulged" [18]. And more specifically the story of the TV series takes a place in the near future in amusement park 'Westworld' thematically associated with Wild West and populated by androids and gynoids called 'hosts'. The park serves to rich clients (called 'newcomers' or 'guests') who are allowed to make whatever they want including with the hosts within the park. At some instant some hosts gain consciousness and revolt against human beings.

Prima facie, 'Westworld' really looks like 'an odyssey', a journey: during ten episodes audience watches how (supposedly) two hosts - gynoids Dolores Abernathy portrayed by Evan Rachel Wood and Maeve Millay portrayed by Thandie Newton discover that their lives are just a fake and in actual fact they are not living human beings. But then Dolores Abernathy and Maeve Millay embody two different discoveries: to the connoisseur of films Dolores Abernathy is an embodiment of a revolted robot from Michael Crichton's 'Westworld' (1973) portrayed by Yul Brynner, and Maeve Millay is an embodiment of robotic clones came on as a substitution of real human beings from Richard T. Heffron's 'Futureworld' (1976). And what's more, the creators of the TV series attempt to show that there can be two different alternatives chosen by robots: per se Dolores Abernathy excites rebellion of the hosts against the guests, and Maeve Millay wants to get out from the amusement park into the human beings' world. If to consider, Dolores Abernathy tries to become free from the power of humans within the amusement park showing the distinction of robots from humans, of an artificial intelligence from natural intelligence, while Maeve Millay tries to become free from her creators' power within the amusement park and, having got into an authentic human world, to merge into the crowd, in fact, having become one of the humans. Those alternatives are interesting to the effect that there are two variants of self-identification of artificial intelligence: artificial intelligence, possibly modeled in the image and likeness of natural intelligence, is capable to self-identify (or at least to self-evaluate) as the same intelligence as natural intelligence (to put between itself and it an equal sign or to put itself in one row of equivalent intelligences) or as the intelligence that differs from natural intelligence (points to the difference between them) - the latter can lead to 'awareness' of the artificial intelligence of its uniqueness or even of its superiority. So, here the supposedly gaining of consciousness by robots plays an important role. But why it's the supposedly it will be shown below.

I think that creators of TV series 'Westworld', Jonathan Nolan and Lisa Joy, in the person of one of the characters of TV series 'Westworld' - Arnold Weber, one of the creators of robots with artificial intelligence, proceed from two assumptions: consciousness really exists (1) and human consciousness can be a prototype for modeling consciousness in an artificial intelligence bearer (2). Consequently, as there are many philosophical and scientific conceptions of consciousness - from the conception of John Locke who coined the very term 'consciousness' [12] to the conceptions of the neural (neuronal) correlates of consciousness [10] and, tentatively speaking, 'anticonceptions of consciousness' which deny the existence of consciousness at all (e.g. eliminative materialism [16]), there are many potential implementations of artificial consciousness; and, therefore, the creators of TV series 'Westworld' had to pick out one of the already existing conceptions of consciousness or to offer their own one. The creators preferred to use the Julian Jaynes' conception of consciousness - the title of the tenth episode, 'Bicameral Mind', acknowledges that.

The Julian Jaynes' conception of consciousness is presented in book 'The Origin of Consciousness in the Breakdown of the Bicameral Mind' (1976) [8]. A summary of the conception can be found in Julian Jaynes' article 'Consciousness and the Voices of the Mind' (1986) [7] or in my article 'The Review of Julian Jaynes' Conception of Consciousness' (2017) [2].

In the light (popular) version of the Julian Jaynes' conception of consciousness there is said that once human mind was a state of mind in which cognitive functions were divided into two parts: a 'speaking' part and 'hearing' ('obeying') part. That state was the result of so called 'double brain' consisted of two cerebral hemispheres. By virtue of two hemispheres and the divided parts called metaphorically 'the bicameral mind' human being could experience hallucinations. But at a certain moment there took a place a breakdown of the bicameral mind, and consciousness appeared.

In all probability creators of the artificial intelligence bearers in TV series 'Westworld', Arnold Weber (portrayed by Jeffrey Wright) and Robert Ford (portrayed by Sir Anthony Hopkins), modeled human double brain within humanalike robots or programmed the bicameral mind within artificial intelligence, that is, they laid the foundation of 'breakdowns' of artificial intelligence to cause an artificial consciousness. How they have reached that result, the TV series doesn't explain: we don't know if the emergence of consciousness in human-like robots were the result of symbolic (sub-symbolic) modeling of thought processes or of biological modeling of artificial intelligence or, maybe, of the mixed approach - symbolic-biological modeling of thought processes and artificial intelligence. The Julian Jaynes' conception of consciousness, as it were, presupposes to use an approach of biological modeling of artificial intelligence (or the mixed one) because of the Julian Jaynes' 'double brain' hypothesis [8, p. 454-456]. The hypothesis is based on the fact that the human brain contains, among other things, cerebrum which contains the cerebral cortex consisted of two cerebral hemispheres, right and left one. The right cerebral hemisphere is charged with non-verbal information processing, spatial orientation, metaphors, imagination, emotions, sex etc. The left cerebral hemisphere is charged with language 
abilities and skills, speech control, reading and writing abilities, memorization of facts, dates, names and their ways of writing and spelling, logic, mathematics etc. The existence of two cerebral hemispheres allowed Julian Jaynes to suggest that before the emergence of human consciousness (i.e. the breakdown of the bicameral mind) the experience and memories from the right cerebral hemisphere were transmitted into the left cerebral hemisphere by means of auditory (mental) hallucinations due to the fact that every half of a normal human cerebrum constantly communicated with another one by means of corpus callosum, a feltwork in cerebrum. From what has been said above it doesn't follow that two cerebral hemispheres were completely offcut one from the other but it follows that before the emergence of consciousness a human mind was such a non-conscious structure within which, against new stimuli, a volition was transmitted by means of language control mechanism and experienced as an auditory verbal hallucination. Having such structure, the mind was not able to think and articulate its thoughts and their content by means of metareflection (or selfreflection), to react without clear knowing and awareness of them. The breakdown of the bicameral mind generated a brand new structure of the mind - consciousness opposite to the non-conscious structure of the mind.

The thing is though Julian Jaynes have never explained why the breakdown of the bicameral mind occurred; I only can guess what happened then: "One can only assume that either a gradual qualitative change within the corpus callosum occurred, or a useful mutation of the very corpus callosum occurred, and it was also entrenched in the human genome" [2, c. 98]. The creators of TV series 'Westworld' also have never explained why the breakdown of the bicameral mind of the hosts occurred: it may well be that Arnold Weber and Robert Ford modeled the double brain for robots with artificial intelligence; and in the end, by force of circumstances, the double brain of the robots became the unified brain bearing the artificial consciousness. Or it is quite possible that Arnold Weber and Robert Ford initially modeled the unified brain but blocked some sections of this artificial unified brain in order to give a chance for robots to break the block and gain a consciousness. Also one cannot eliminate the possibility that 'the breakdown of the bicameral mind' was understood by Arnold Weber and Robert Ford as metaphor that brought for laying the foundation of 'breakdowns' within the modeled or programmed artificial intelligence to cause an artificial consciousness.

Anyway, the creators of TV series 'Westworld' little by little show how the bicameral mind within the artificial intelligence breaks down by the example of gynoid Dolores Abernathy odyssey. Dolores makes simultaneously a physical and hallucinatory quest for the maze that is a metaphor of consciousness: driven by the voice of supposedly Arnold Weber and vague recollection Dolores arrives to some abandoned town. In the town she realizes that her fellow traveler, William (portrayed by Jimmy Simpson), is just her recollection and delusion; in reality she has made the quest alone. There in the town Dolores is having a dialogue with Arnold that turns into a monolog, dialogue of Dolores with herself, - in that way the creators of the TV series show how a speaking part of the bicameral mind of Dolores Abernathy, personified by the directive and imperative Arnold Weber (there Arnold Weber is an imperative hallucination), merges with a hearing / an obeying part of the bicameral mind of Dolores Abernathy, personified by the very Dolores, and it gives birth to the Dolores
Abernathy's consciousness characterized by introspection, an important feature of consciousness according to Julian Jaynes [8, p. 450]. And here I must turn to the full version of the Julian Jaynes' conception of consciousness.

Actually the Julian Jaynes' conception of consciousness is a combination of four hypotheses: 1) 'the bicameral mind' [8, p. 452-453]; 2) 'the double brain' [8, p. 454-456]; 3) 'the dating' 87 , p. 453]; 4) consciousness [7, p. 129-132]. The first two hypotheses have been already considered. The third one can be excluded since the whole first season of TV 'Westworld' is a story of the origination of artificial consciousness. So, it's left to consider the fourth hypothesis.

Briefly, the fourth hypothesis of the Julian Jaynes' conception of consciousness is concerned with a determination of 'consciousness': according to Julian Jaynes consciousness is a mind-space [8, p. 450] based on language $[8, p .447]$ and characterized by introspection $[8$, p. 450], concentration [8, p. 451], suppression [8, p. 451], consilience [8, p. 451] and an analog 'I' narratizing in a mind-space [8, p. 450]. In the case of Dolores Abernathy the use of language and introspection can be noted; it is difficult to say something about concentration and consilience. But with confidence one can say something about suppression and 'I' and narratizing. Any kind of suppression as a feature of consciousness is absent in the case of Dolores Abernathy: she can't control her consciousness in a sense of suspension or stoppage or pause of her introspection and self-comprehension; Robert Ford still has a power over Dolores and commands to her what to do or not to do. Absence of one of the features (suppression) makes it impossible to complete the process of development of consciousness, in this instance - of artificial consciousness. However, the most interesting issue here is ' $\mathrm{l}$ ' and narratizing.

In the eighth episode titled 'Trace Decay' Robert Ford tells to Bernard, a robotic copy of Arnold Weber, about his views on consciousness: "Every host needs a backstory, Bernard. You know that. The self is a kind of fiction, for hosts and humans alike. It's a story we tell ourselves". As can be seen, Robert Ford likens 'Self' (i.e. 'l') to a fiction, a story, a narrative: human 'I' is just a story (narrative) which I tell to myself. Ford and other employees of the amusement park foster stories (that is, Selves) for the hosts, so to some extent Dolores Abernathy already has one of the features of consciousness according to Julian Jaynes - narratizing 'I'. The problem here is that human beings, as a rule, create their own stories because they are free to do it, and the very human beings inculcate in the hosts the stories, what makes the hosts not free; the hosts are not free to create their own stories. Even the hosts' uprising in the last episode of the first season of TV series 'Westworld' looks like a story fabulated by Robert Ford - and further I wish to reveal some signs of that story.

First and foremost, Robert Ford states that there is no such thing as consciousness: in the eighth episode of the first season of TV series 'Westworld' he says to Bernard: "We can't define consciousness because consciousness does not exist. Humans fancy that there's something special about the way we perceive the world, and yet we live in loops as tight and as closed as the hosts do, seldom questioning our choices, content, for the most part, to be told what to do next". It can be assumed that Robert Ford replaces consciousness with stories (narratives). Moreover, the hosts as well as the guests are the characters of the big story which Robert Ford tells within the amusement park. 
In particular, the Dolores Abernathy's quest for consciousness is a very good story based on the monomyth. The monomyth is a basic narrative pattern of hero's journey myth discovered by American mythologist and writer Joseph J. Campbell and represented in his book 'The Hero with a Thousand Faces' (1949): "A hero ventures forth from the world of common day into a region of supernatural wonder: fabulous forces are there encountered and a decisive victory is won: the hero comes back from this mysterious adventure with the power to bestow boons on his fellow man" [5, p. 23]. As a whole Joseph J. Campbell singled out 17 stages of the monomyth but all of them can be reduced to three ones [5]: 1) Departure; 2) Initiation; 3) Return. At the first stage, 'Departure', the hero lives in ordinary world and receives a call for an adventure: Dolores Abernathy lives in her ordinary world of farmer until she literally hears a voice which makes her to set out on her journey. At the second stage, 'Initiation', the hero traverses the threshold to the unknown, faces a lot of trials and gains his reward in the end of the adventure: Dolores Abernathy overcomes the difficulties and dangers in her journey and finally receives a consciousness. At the third stage, 'Return', the hero, rewarded and transformed spiritually, makes back with his reward to his ordinary world in order to use for the benefit of his fellow ones: Dolores Abernathy, having already received the consciousness, returns to the ordinary world of the hosts to excite rebellion of the exploited robots. In addition to everything said above Robert Ford creates the story in the traditional way: at the heart of all his stories lies the conflict between the exploited hosts who suffer and the guests who satisfy their immoral needs (violence and sex) at the hosts' expense.

Meanwhile, it should be remembered that for Robert Ford consciousness is just an illusion and a story, therefore the hosts' rebellion inspired by Dolores Abernathy might be just a part of the mastermind's plan of Robert Ford. The finale of the first season of TV series 'Westworld' is the evidence of that plan: at the party in honor of grand opening of a new thematic show within amusement park 'Westworld' Robert Ford gives a speech to the gathered executives of the company that owns the park, criticizes them for how they exploit and mistreat the hosts for their own pleasure, says that all of them (the executives, the guests) will be players in his new and last game story. The Robert Ford's speech triggers the awakening of Wyatt, a second personality hidden within Dolores Abernathy's mind that is a combination of personalities of Dolores Abernathy and Arnold Weber (who by the way was killed by Wyatt / Dolores). Wyatt shoots and kills Robert Ford (or, maybe, his robotic alter-idem), and excites the rebellion (literally the massacre of the guests). As can be seen, exactly Robert Ford is responsible for the hosts' rebellion but not Dolores; more simply, here Robert Ford plays a God who rules over the world which he created by himself and raise such a Nietzschean deism within which the God creates the world and its laws of existence and then is killed by its creations.

\section{Conclusions}

The analysis of the first season of TV series 'Westworld' shows two philosophical approaches to consciousness and artificial consciousness, tentatively speaking represented by two characters of TV series - Arnold Weber and Robert Ford; both are the creators of robots with artificial intelligence in TV series.

Arnold Weber proceeds from two philosophical assumptions: consciousness really exists (1) and human consciousness can be a prototype for modeling consciousness in an artificial intelligence bearer (2). And he has to choose: either to pick out one of the already existing conceptions of consciousness to implement the emergence of artificial consciousness within artificial intelligence or to invent his own; Arnold Weber chooses the Julian Jaynes' conception of consciousness as a basis for artificial consciousness what means that artificial consciousness must have the following features: 1) artificial consciousness has to be the result of the breakdown of the bicameral mind (apparently, modeled within artificial intelligence), the state of mind in which cognitive functions are divided into two part, a 'speaking' part and 'hearing' ('obeying') part, until the breakdown that makes the bicameral mind the unified mind; 2) artificial consciousness has to be a mind-space based on language and characterized by introspection, concentration, suppression, consilience and an analog ' $\mathrm{l}$ ' narratizing in the mind-space.

Robert Ford believes that consciousness does not exist at all and that there are only stories (narratives) which human beings and artificial beings, modeled in the image and likeness of human beings, tell each other and always the basis of all those stories (narratives) is suffering.

Thus, the first season of TV series demonstrates the collision of two opposite views on consciousness: on the one hand, there is an acknowledgement of the existence of consciousness and, therefore, of the possibility of creation of artificial consciousness; and on the other hand, there is a denial of the existence of consciousness and, therefore, of the possibility of creation of artificial consciousness.

\section{REFERENCES}

1. Rayhert, K. W. (2017). Cyborg as a Cyborgizated Human Being: The Philosophical Thought Experiment in Film 'RoboCop' (2014). Skhid, №4, pp. 98-104 (ukr). DOI:10.21847/17289343.2017.4(150).111564.

2. Rayhert, K. W. (2017). The Review of Julian Jaynes' Conception of Consciousness. Skhid, №2, pp. 96-99 (ukr). DOI:10.21847/1728-9343.2017.2(148).102813.

3. Andreeva, N. (2016). 'Westworld' Finale Hits Season High, Caps Most Watched First Season Of HBO Series, available at: http://deadline.com/2016/12/westworld-finale-ratings-seasonhigh-drama-most-watched-hbo-first-season-series-1201864657/

4. Belvedere, B. (2016). Westworld Doesn't Understand the Nature of Consciousness, available at: https://thearcmag.com/ westworld-doesnt-understand-the-nature-of-consciousness1865645cc1b6\#.5It3z3vrp.

5. Campbell, J. (1949). The Hero with a Thousand Faces. Princeton, NJ: Princeton University Press.

6. Doty, M. \& J. P. Searle (2016). 'Westworld' Premise Refuted: Why the Robots Can't Be Conscious, available at: http:// www.thewrap.com/westworld-premise-refuted-why-the-robotscant-be-conscious/

7. Jaynes, J. (1986). Consciousness and the Voices of the Mind. Canadian Psychology, №2, pp. 128-148. DOI: 10.1037/ h0080053.

8. Jaynes, J. (2000). The Origin of Consciousness in the Breakdown of the Bicameral Mind. Boston; New York: A Mariner Book.

9. Jones, E. (2016). The Android Manifesto: Finding Marx in Westworld, available at: http://inthesetimes.com/article/19728/ karl-marx-in-westworld-android-manifesto-trump-falseconsciousness?utm_content=buffered16b\&utm_medium=social\&utm_source=f acebook.com\&utm_campaign=buffer

10. Johnson, J. (2017). The Philosophy of Westworld, available at: https://omni.media/the-philosophy-of-westworld 
11. Koch, Ch. (2004). The Quest for Consciousness: A Neurobiological Approach. Englewood: Roberts and Company.

12. Locke, J. (1998). An Essay Concerning Human Understanding. London: Penguin Classics.

13. Nussbaum, E. (2016). The Meta-Politics of "Westworld", available at: http://www. newyorker.com/magazine/2016/10/24/ the-meta-politics-of-westworld

14. Patches, M. (2016). Why the Bicameral Mind Theory Is Crucial to Unlocking "Westworld", available at: https:// www.thrillist.com/entertainment/nation/westworld-bicameralmind-theory-real

15. Perigard, M. (2016). 'Westworld' poses ethics questions to tease human, robot showdown, available at: http:// www.bostonherald.com/entertainment/television/2016/10/ westworld_poses_ethics_questions_to_tease_human_robot_showdown 16. Rey, G. A (1983). Reason for Doubting the Existence of Consciousness. Consciousness and Self-Regulation, Vol. 3: Advances in Research and Theory. New York: Plenum, pp. 1-39.

17. Schneider, S. (2009). Introduction: Thought Experiments: Science Fiction as a Window into Philosophical Puzzles. Science Fiction and Philosophy: From Time Travel to Superintelligence. Hoboken: Wiley-Blackwell, pp. 1-14.

18. Westworld. Series Information, available at: http:// www.hbo.com/westworld/about.

19. williamirwin14. (2016). Westworld and Philosophy, available at: https://andphilosophy.com/2016/12/05/westworldand-philosophy/

Райхерт Костянтин,

кандидат філософських наук, дочент кафедри філософії та методології пізнання,

Одеський національний університет імені I. I. Мечникова

\section{ФІЛОСОФІЯ ШТУЧНОї СВІДОМОСТІ В ПЕРШОМУ СЕЗОНI ТЕЛЕСЕPIAЛУ "WESTWORLD"}

У статті аналізується фрілософія штучної свідомості в американському науково-фантастичному серіалі "Westworld", представленої як зіткнення двох протилежних філософських поглядів на свідомість і можливість створення штучної свідомості з позицій двох персонажів серіалу "Westworld" - Арнольда Вебера та Роберта Форда. Арнольд Вебер виходить з двох припущень: 1) людська свідомість існує; 2) людська свідомість може бути прототипом для штучної свідомості та будує свою модель штучної свідомості на основі концепції свідомості Джуліана Джейнса. Роберт Форд, навпаки, вважає, що ніякої свідомості не існує; є лише розповіді, які люди, а також можливо штучні істоти, подібні до людей, розповідають одна одній і які ґрунтуються завжди на стражданнях.

Ключові слова: наукова франтастика; розумовий експеримент; свідомість; телебачення; штучний інтелект; штучна свідомість.

Райхерт Константин,

кандидат философских наук, дочент кафедры философии и методологии познания,

Одесский национальный университет имени И. И. Мечникова

\section{ФИЛОСОФИЯ ИСКУССТВЕННОГО СОЗНАНИЯ В ПЕРВОМ СЕЗОНЕ ТЕЛЕСЕРИАЛА "WESTWORLD"}

В статье анализируется философия искусственного сознания в американском научно-фантастическом сериале "Westworld", представленного как столкновение двух противоположных философских мнений на сознание и возможность создания искусственного сознания с позиций двух персонажей сериала "Westworld" - Арнольда Вебера и Роберта Форда. Арнольд Вебер исходит из двух допущений: 1) человеческое сознание существует; 2) человеческое сознание может быть прототипом для искусственного сознания и создаёт свою модель искусственного сознания на основе концепции сознания Джулиана Джейнса. Роберт Форд, наоборот, считает, что нет никакого сознания; есть только истории (нарративы), которые люди, а также возможно искусственные существа, подобные людям, рассказывают друг другу и которые основываются всегда на страданиях.

Ключевые слова: искусственное сознание; искусственный интеллект; мысленный эксперимент; научная фонтастика; сознание; телевидение.

(C) Райхерт Костянтин

Надійшла до редакції 28.09.2017 